\title{
Adaptation and the Question of Cost-Effective Change: Outlining Socio-Ecological Exertion of Khasi in Bangladesh Context
}

\author{
Choudhury Farhana Jhuma \\ Department of Anthropology, Shahjalal University of Science and Technology, Sylhet, Bangladesh \\ Email: farhanajhuma@yahoo.com
}

How to cite this paper: Jhuma, C. F. (2020). Adaptation and the Question of Cost-Effective Change: Outlining Socio-Ecological Exertion of Khasi in Bangladesh Context. Open Journal of Social Sciences, 8, 412-428. https://doi.org/10.4236/jss.2020.88034

Received: July 16, 2020

Accepted: August 25, 2020

Published: August 28, 2020

Copyright $\odot 2020$ by author(s) and Scientific Research Publishing Inc. This work is licensed under the Creative Commons Attribution International License (CC BY 4.0).

http://creativecommons.org/licenses/by/4.0/

\section{(c) (i) Open Access}

\begin{abstract}
The enduring problems of economic mobility of Khasi people through "access-condition imperatives" have reflected in the discussion from the cultural, ecological perspective. The study illustrates that the traditional culture of Khasi people has regulated stratified access to natural resources. The modernize effort of the community towards coping with environmental limitations is typically inducing actor-oriented rather than community-based absorption of adaptation practice. The process of sustainable development requires holistic consideration of change from the socio-cultural encompasses of natural resources. The research works on the limited understanding of adaptation in the context of the co-existing reality of a small scale society with a dominant socio-cultural environment. Finding the cultivation as the reduced practice for the indigenous Khasi, relatively it was in the tradition, the theoretical stand of Neo-Marxist philosophy has followed at this point. The idealized and judgmental practice of specified social relation of Khasi cultivation has an address here with cultural principles, elaborating the pattern of capital intensive changes generating in the access-conditions of "land" use. The implication of modern heterogeneous society requires the necessity to ensure the reproduction and sustainability of a changing social system. The ecological cost-benefit understanding should emphasize positive feedback, concentration on ethno-political and cultural flow trends, and a purposive modification of social value. The purposive change does not mean the closure of traditional practice but promotes the practice where it found an ecological rationale for community interest.
\end{abstract}

\section{Keywords}

Ramified Relationship, The Pattern of Adaptation, Small Scale Society, Positive Feedback, Khasi Rationality 


\section{Introduction}

The existence of small scale societies in the changing market economy has always gained the interest of anthropology. Much research has been undertaken over the nineteenth century to discover the relation of the environment with the existence of small scale societies and traced various dimensions in patterns of change (Matley, 1982; Simoons, 1979; Kroeber, 1939; Steward, 1955; Barth, 1956). The debate on the delineation between biological and social adaptation is the post-socio-natural academic concern in ecological anthropology. The debate concentrates on the fact that socio-cultural adaptation is human-modified, diverse, vibrant, and complex phenomena on opposing of coherent biological adaptation (Bargatzky et al., 1984). Socio-cultural adaptation needs extra-care to implement and declare the aim and goal of adaptation. Roy Ellen (1982) has given the formula of ensuring "just" and "sustainable" adaptation policy framework through a coherent trade network system of a small scale society. The characteristics and preconditions he has outlined are not available and follow in a stratified environmental and socio-cultural setting. The unequal power relation has created an imbalance that neither can adjust with the homeostasis procedure of positive feedback with systemic inclusiveness formula prescribed by Roy Ellen, nor can it explain with the all-encompassing ecosystem notion of Rappaport (1967) and Vayda (1969) through negative feedback as the sovereign governmentality relation exists between state and the population. The research aims to explain the limitation of the mainstream adaptation process in the management of limited natural resources in the centralized and stratified ecosystem platform. The adaptation in the name of adjustment with alternative use of resources through access regulation policy both from cultural and national apparatus reflects the misleading as the internal and external socio-cultural relation is stratified from economic social and political aspects (Drong, 2012; Patam, 2005). In Khasi social formation $^{1}$, the traditional rules and the pattern of the change have presented here by the two-fold influence of Khasi social practice. The one is internal social institutions that influence in the cultivation relation of Khasi living from generations. Secondly, the changing form has identified according to external and internal networking and motivations of broader interest of natural recourse use justification and land use regulations. The ramified relationship ${ }^{2}$ process reflects in the Khasi social practice, e.g. labor mobility, production type, profit accumulation system, hierarchy system, and land utilization system. The interaction of environmental resources and social institutions in the production process of Khasi determines the local conditions and dominance and dependence of scenarios of limiting factors for traditional subsistence. The process comprises socio economic regulation system focusing on local conditions and practiced stratified

\footnotetext{
${ }^{1} \mathrm{~A}$ social formation is an empirical configuration of the processes and relation between human individuals and populations through which value, religion, or belief exchanged (Ellen, 1982).

${ }^{2}$ Focusing on the specific relationship between the human population and the features of their environment directed attention towards the existence of ramification of a specific relationship (Ellen, 1982).
} 
access in environmental resource utilization through hierarchical recognition of access and ownership of natural resource e.g. land. The human induce cause-effect calculation of nature-culture relation promoted the "mechanical model" of adaptation is the early 19th century scholarly contribution and has identified as limited and misleading facts regarding socio-cultural relation of adaptation. The study finds that the traditional and modern way of living of Khasi has not minimized the stratified relation of natural use of resources for subsistence. The social system's role in producing and maintaining stagnation in economic mobility and competitive use of environment through social value system and the market economy has discussed here with traditional and modernity practices in the context of subsistence relations in the Khasi community of Jaflong, Sylhet.

\section{Background of the Study}

The objective explanation of energy, nutrition flow has gained the interest of the thinkers of the 1990s. This interrelation between biotope and habitat gave rise to the ecosystem concept in human adaptability. The boundary approach, niche identification, and selecting the ecosystem in terms of geographical scale have gradually introduced. Though it starts with the related group and defined territory, for Barth (1956: p. 1079 in Ellen, 1982: p. 82), the "mobility model" demonstrates the principle of give-and-take relation of environmental resource exchange. Barth (1956) has applied the model "negotiation" among entirely different groups based on environmental specifications. The recognition of the "culture area" of Barth (1956) can provide the scope of alternative employment needs. Barth suggested multipurpose society with flexibility in a social system such as power, class, and economy.

The "container model" identifies patterning the flexibility with neo-liberal rules and regulation that it is a discipline for Foucault (Molland, 2018). For the survival of Statehood and governmentality, the multilayered, complex socio-economic and varied regulatory, geographic relation needed (ibid, p. 116). In auxiliary R. Rappaport (1967), through the cybernetic approach, shows how ritual can act to adjust the balance between a population and its resource, and gave meaning to a world through culture and ritual (Moran, 2000: p. 60). For Rappaport, the aesthetic components such as social value, norms have material meaning for environmental coping. Vayda (1969) describes that political organizations such as state, liberal perspective, and cultural components are necessary for ecological benefit. C. Conklin (1957) and Bicchieri (1972) classified the production process through behavior. C. Geertz (1963) likewise analyzed population support and labor cost from a dynamic historical perspective. Embodying modern farming, J.W. Bennett (1976) found the policy-oriented culture control over resources resulting of rational choice. Here technology use depends on institutional and technological consideration rather than the value-oriented ideological outcome.

In asserting the role of culture at this changing phase, the discussion reflects 
that individual behavior and cultural interaction happen through a value system. Ellen (1982) affirmed, in a deficient intensive production case, negative feedback/output occurs. In high-intensity production, positive feedback occurs as consumption, export, and import remain functioning. Ellen (1982) clarifies the need for exchange for avoiding concentration in a particular component in a patterned group. Although the efficiency categories are the base of inequality, dominant and dependency create barriers in a system and should convert to openness with the culture apparatus. Here new technology innovation does not work only. The open system depends on the transformation of effort and information on efficiency.

The specification of the Khasi social system identified by Hamlet Bareh (1997) comprises the social hierarchy and norms in access in ecological distribution system. Bareh (1997) describes as Khasi does not practice cross-cousin marriage. Khasi avoids the marriage of first and second cousins because of the classified rule of sibling recognition. The corporate group in the economic sector goes with symbolic social status group of Khasi selection of social leaders, i.e. Syiem, Jamindar, and Myntri. Presently the Jamindar and Myntri do not get any economic benefit for holding the position and do not control the individual production process. Khasi does not involve property holding with lineage or marriage and common property rights had controlled by "ling" or ancient household according to genealogy. The dent of individual ownership is a weakness in economic mobility in Khasi tradition that has raised by new generation market economy based economic earners.

In explaining nationalist power Sanjeeb Drong (2012) assertion on identifying the adversity of Khasi and other indigenous communities, the external and macro aspects have traced. According to Drong, "for centuries, the indigenous peoples in Bangladesh have been facing the severe effects of government policies like land grabbing, forceful migration, and human right violation, including the colonial policy of divide and rule. Outsiders took lands from the indigenous peoples. After the loss of land, many of these indigenous people migrated to the towns and cities for jobs".

The two dimensional but interrelated socio-cultural obligation has patterned the access of Khasi in natural resource use and inducing stratified social reproduction. The process has discussed with describing social heterogeneity in social settings of Khasi community of the study area.

\section{Theoretical Perspective}

\subsection{The Implication of Culture}

The small scale society of modern socio-economic system embraces influence of embedded factors. The flow of labor in environmental resources is ordered primarily by culture. The access of the same entity in modern times has directed by the state policy and legal framework. In criticizing Carneiro (1968), Bargatzky et al. 1984 stated that "culture is not always adaptive towards nature" (p. 3). Taking 
forward Alkire (1960) and Meggitt (1972) states that human population are not adaptive to their environment through their institutions. Moreover institutions purposively use the resources of the environment (Bargatzky et al., 1984: p. 3). The hierarchical control system of culture (Ashby, 1954 in Bargatzky et al., 1984) has addressed at this point. The precondition for "systemic inclusiveness" (Ellen, 1984: p. 195) through a mutual transfer of resources (personnel, genes, energy, materials, and value or any kind of aesthetic components) is possible in relatively "undisturbed" and "self-controlled" societies. The external factors and challenges that Ellen (1984) has stated "extrinsic factors" are apparent in colonial and post-colonial condition (Geertz, 1963) and the ecological ${ }^{3}$ meaning of changing patterns of the social system is enhancing different thought in explaining adaptation and challenges in the socio-natural interaction field. According to Sahlins (1957), the "meaning of environment" is generated through the social structure's material and energetic requirements. The relevancy of the meaning has attached to human's symbolic possession of its natural resources. Kaplan and Manners (1972) render that man's environment is increasingly a cultural environment (Bargatzky et al., 1984). The concepts of resilience, behavioral disposition, movement reflex the unequal interference of these patterns of resource access.

\subsection{The Implication of the Market}

Friedman (1974) placed the need to differentiate the factors "operators" and "constraints" to specify that "culture determines access to basic resources", i.e. types of land use. The environmental limitations generally minimize the process of networking with immediate and convenient neighbors from the perspective of "positive feedback" (Ellen, 1982), but maintaining change according to local significance is crucial to ensure internal coherence and sustainability. Ellen (1982) mentioned the functions of internal and external types of asymmetry that induce shortfall in particular resources, and the short and long ended trade expands to mitigate the shortage. In the political, ecological view, the resource distribution and negotiation are unequal and power centric in a stratified context. Continuation of Escober 1996, Fletcher 2010, Hulme 2009, Milton 1993, and others focused on the disposition of local resource base economy with the involvement of global force, state, and market (Karlsson, 2015). Wolf (1972) reflects on the complexity of addressing the components, i.e. "access, control, and ownership of land" in a capitalistic era where non-local and local elites are unavoidable and crucial (Karlsson, 2015: p. 351). The idea of "embodied land" (Hornborg et al., 2007) on protesting market-induced land production measures has found rational in local-global interaction of change.

The socio-natural and political stimuli of adaptation is a complex dynamics

${ }^{3}$ It is concerned with the interplay between human population behavior and environmental variable in terms of personal and temporal relations involving the exchange of energy, material, and information. It is anthropological rather than ecology focused on physiological and genetic relations. Ellen 1982: preface: $x i$. 
(Head, 2010). The proposed approach of "new ecology" emphasizes the process of "public discourse" analysis with the ambition that necessary cultural changes will occur at the intersection of individual, social and institutional behavior and attitude (Lorenzoni et al., 2007 in Head, 2010: p. 238). The neo-liberal trends of "emphasis on economy and neglect of values" has proposed to overcome by dialogue between policy aspect of the environment, society, and economy (Klaus 2010 in Lapka et al., 2012). Here the Steward's (1955) fallacy has revised by admitting that environmental problems are the enhanced part of cultural complexity and cannot solve with sole technological improvement and mainstream imperatives, i.e. education, capital centric income generation, or infrastructural development.

Here the adaptation limitation perspective of nature-culture ecological theory has discussed the role of culture in the patterned absorption of subsistence access and limitations of modernization in providing space according to "local significance" Ellen (1982) for alternative socio-economic access has influences on the stratified socio-economic changes in Khasi community.

\section{Research Methodology}

\subsection{Study Area}

The paper focuses on the socio-economic change and coping pattern of the Khasi community. The objective of the research is to know the pattern of involvement in a diversified substance system as resource limitation coping strategy in Khasi. The qualitative study follows an in-depth interview, life history, and unstructured interview with indigenous respondents. The Khasi expects traditional leader's consent and support to make any formal appearance. With rapport-building the researcher seeks Khasi leadership support to involve in proceeding the qualitative methods and critical informant selection. Besides, in Khasi social composition, household plays a vital role in all kind of decision making and social mobility aspect. The household is the representation of matrilineal functioning in the system.

The study selected respondents from different ages, gender, skills, and economic segments to understand the diversity in the subsistence practice of Khasi. The study conducted for the consecutive period of June 2014-June 2015 as a part of the author's Ph.D. framework. However, the longitudinal observation has continued periodically until early 2019. The traditional Khasi household has considered here as the unit of study. Accordingly, a selected household members is the respondents of the research. To trace the pattern of diversity in the involvement of subsistence activities, purposive selection of individuals from government and non-government offices and of different ethnic groups are also minimally included as informants.

${ }^{4}$ In Khasi system, iing means "household and carries the broad meaning of lineal relationship". The collective identity of iing influences Khasi to consider all types of earning of household members as the common property of ling, and the earning should spend on the common interest of descents. This shared identity protects Khasi to develop nuclear households. 
The household has categorized in the traditional settlement order, i.e. 1) Iing ${ }^{4}$ : Ancestral houses, 2) Para: Brothers and Sisters house situated beside the iing, 3) Kur: First Cousin houses in the Punji 5 , 4) Shelters and dependents houses, 5) Household with no kinship relation with others. The household category has selected from the eight Punji of the studied area naming Nokshier, Bollah, Protappure, Mukampunji, Jaintiapure Mastinghati of Jaflong ${ }^{6}$, furthermore, Jointiapure thana ${ }^{7}$ Of Goainghat Upozila ${ }^{8}$ of Syhet, the north eastern region of Bangladesh. Among the total of 140 households, systematic random selection method have followed to select 89 households. A yearlong fieldwork, partial participation and observation, key informant interviews, and semi-structured interview methods have followed to understand the diversity of subsistence practice and household response on traditional cultivation opportunities. The pattern of change has discussed through four social indicators, e.g. settlement, subsistence, the pattern of the neighborhood, and education access.

\subsection{Diversity in Khasi Social System}

Throughout the year, Khasi keeps in the process of entry and exit into the cultivation area of different Punji. This temporary and periodic migration of Khasi influences the total population in the Punji. During the fieldwork period, the population found partly in the household; some members remain absent because of purposive migration to other Punji.

According to the pattern of residence, the informants have divided into two categories. These are permanent residents and temporary residents. The absentee population is necessary for identifying the total population as they are the members of the Punji and household. The migrants have chances to change the actual figure. The total population becomes less or more from the mentioned Table 1 records.

Here, in Table 2, the socio-economic involvement of sampled respondents has presented. The total household has identified according to Khasis long-term inhabitancy on the respective area and the relevance to betel leaf Jum cultivation as a subsistence pattern. In Mastinghati and Jaintia, the household's sample size has identified according to social recognition and long-term settlement in the Punji as the occupation is diversified.

\section{Specification of Ramified Relationship}

The findings have presented by theorizing the concept "change" as a rational choice followed by the prevailing of the factors, i.e. social considerations, market

${ }^{5}$ Punji is the clustering of kin-based households representing the Khasi tradition of living. ${ }^{6}$ Jaflong is a union under Goainghat Thana in Sylhet Sadar Subdivision. There is a village with the same name in the Jaflong union. It is mainly a tea state situated at the foot of the Khasi Hills.

${ }^{7}$ Thana is the administrative unit of the district. There are 10 Thana in Sylhet Sadar subdivision in Pakistan period (east Pakistan district gazetteers: 404).

${ }^{8}$ Upazila is the unit of local government administration under a subdivision. Jaintiapur and Goainghat Upazila created on 25 December 1941 and 22 September 1941, respectively, under Sylhet Sadar Sub-division. 
demand, capital intensive production, and modernization issues existing in Khasi social practice. Tables and analysis have outlined the lack of available facility inclusiveness in different aspects of the cultural practice of the Khasi of the study area.

\subsection{Khasi Internal Social Formation and Tendency of Change}

The practice pattern of a social institution and its influence in the cultivation system has outlined to explain the adaptation. Khasi social system comprises traditional rules in the cultivation process with the indication of entering the changing pattern of social forces. Here the Khasi cultivation system based on subsistence technique and kinship pattern has been discussed to identify the social formation. The emphasis has given to the components of local conditions. The Punji social formation is influenced by changes in cultivation relations. The local condition has described here from the aspect of the community.

Table 1. Households according to Punji location.

\begin{tabular}{ccccc}
\hline Location & Total Household & Sample Size & Population & Population Sample Size \\
\hline 8 Punji & 140 & 89 & $1296^{*}$ & 440 \\
\hline
\end{tabular}

Fieldwork: 2014-15. *Gain and Malik (eds.) 2007.

Table 2. The diversity of dependency in each category of social components.

\begin{tabular}{|c|c|c|c|c|c|c|c|}
\hline $\begin{array}{l}\text { Location } \\
8 \text { Punji }\end{array}$ & $\begin{array}{l}\text { Sangram (old) } \\
\text { Sangram (New) }\end{array}$ & Noksier & Protappure & Borolla & Mukam & Mastinghati Jaintia & Total \\
\hline \multicolumn{8}{|c|}{ 1) The primary source of subsistence according to the household (sample size) } \\
\hline $\mathrm{Jum}^{9}$ & $12(52.17 \%)$ & $7(46.6 \%)$ & $8(54.14 \%)$ & $2(22.2 \%)$ & $4(33.33 \%)$ & $2(12.5 \%)$ & $35(39.3)$ \\
\hline Business & $5(21.73 \%)$ & $3(20 \%)$ & $3(21.42 \%)$ & $2(22.2 \%)$ & $4(33.33 \%)$ & $4(25 \%)$ & $21(23.6 \%)$ \\
\hline Service & $2(8.69 \%)$ & $2(13.33 \%)$ & $1(7.14 \%)$ & $1(11 \%)$ & $1(8.33 \%)$ & $9(56.25 \%)$ & $16(18 \%)$ \\
\hline Combination & $4(17.39 \%)$ & $3(20 \%)$ & $2(14.28 \%)$ & $4(44.4 \%)$ & $3(25 \%)$ & $1(6.25 \%)$ & $17(19.1 \%)$ \\
\hline \multicolumn{8}{|c|}{ 2) Relationship pattern inside Punji according to household (sample size) } \\
\hline Kin Group & $14(60 \%)$ & $11(73.3 \%)$ & $7(50 \%)$ & $3(33.3 \%)$ & $4(33.33 \%)$ & $3(18.7 \%)$ & $42(47.19 \%)$ \\
\hline Marital Group & $5(21.7 \%)$ & $2(13.3 \%)$ & $3(21.4 \%)$ & $2(22.2 \%)$ & $5(41.6 \%)$ & $2(12.5 \%)$ & $19(21.34 \%)$ \\
\hline Non-Kin Group & $4(17.39 \%)$ & $2(13.3 \%)$ & $4(28.5 \%)$ & $4(44.4 \%)$ & $3(25 \%)$ & $11(68.7 \%)$ & $28(31.5 \%)$ \\
\hline \multicolumn{8}{|c|}{ 3) The pattern of Education Punji/Population (sample size) } \\
\hline Traditional & $61(67.8 \%)$ & 44 (55\%) & 57 (71.25\%) & $23(57.5 \%)$ & $35(58.33 \%)$ & $23(25.55 \%)$ & $243(55.2 \%)$ \\
\hline $\begin{array}{c}\text { Modern (Below } \\
\text { Higher Secondary) }\end{array}$ & $22(24.44 \%)$ & $23(24.44 \%)$ & $14(17.5 \%)$ & $11(27.5 \%)$ & $17(28.33 \%)$ & $48(53.33 \%)$ & $135(30.6 \%)$ \\
\hline $\begin{array}{l}\text { Modern (Higher } \\
\text { Secondary }\end{array}$ & $7(7.8 \%)$ & $7(7.8 \%)$ & $9(11.25 \%)$ & $6(15 \%)$ & $8(13.33 \%)$ & $19(21.11 \%)$ & $62(14 \%)$ \\
\hline
\end{tabular}

Source: Fieldwork 2014-15.

${ }^{9}$ Jum is the local term of Khasi to understand the traditional Khasi cultivation of land. Jum represents Khasi pattern of land ownership, division unit among the land area, unit of measurement of land property, and type of affluence of Khasi. 
Punji has ordered in Table 2 accordingly to represent the distance of respective Punji from the town area. Here distance of Sangram Punji from local inhabitance is the longest. Mastinghati and Jaintia are the closest Punji of local inhabitancy and have functional diversity among the inhabitants. The difference in subsistence in Section 5 of Table 2 shows the pattern of availability of resources in the particular Punji. In Punji, households mostly depend on a combination of income from different sources of resource use. In Sangram Punji, Khasi depends on cultivation in major, (52\%). Households depending on income coming from other sources are $17 \%$. In Noksier Punji, the primary subsistence is Jum (46\%), and dependency on service and business is mentionable (13\% and $20 \%$ respectively). Lama-Protappure depends on Jum insignificant (54\%). In Borolla Punji, dependency on a combination of different sources is significant (44\%). The dominant subsistence of Jaintia and Mastinghati is service (56\%). The difference in various subsistence patterns is found marginal in Mukam Punji.

The necessity of alternative resource is used in Khasi Punji given the shortage of availability of environmental resources in maintaining a livelihood. The cultivation maintained according to kinship relation. G. P. Murdock (1949) in his description found that "A rule of descent affiliates an individual at birth with a particular group of relatives with whom he is especially intimate" (Murdock, 1949 in Chowdhury, 1998: p. 127). The opinion reflects that Khasis follows strong "we" and "they" relation among the descent line and the community. Traditionally, though the Punji represents a homogenous group of Khasi, the diversity in social bondage has found, representing the stratification in the traditional pattern of Punji formation. Punji represents the exogamous kin group. There are other households in the Punji that are not the close relative of common genealogy but related by affinity or marital bonds. These households mostly migrated from other places. The Punji features the traditional pattern of exogamous kin relationships inside the Punji. In Jaintia Punji, the various interest groups reside in the Punji. The presence of inhabitant from different genealogy (Kur) represents the effectivity of exclusion and inclusion rules in the cultivation process.

The collective identity of ling influences Khasi consider all types of earning of household members as the common property of ling and the earning should spend for the common interest of descents. Khasi, of the Pnar group, the son is responsible for the rights and duties of his family even after his marriage. His hierarchical property belongs to his mother and even in his acquired property and income-his mother has rights. He is not with his wife's family as much as he is involved with his mother's family. The access barriers in the context of fulfilling kinship facilitation in cultivation have become gradually in a decrease in the Punji.

There the presence of missionary and initiatives of advocacy of general education facilitate the need for mainstream education among the Khasi. In Sangram Punji, Noksier, Lama and Protappure, Borolla, and Mukam Punji, most of Khasi are in traditional living. However, the new generation of Khasi found attending 
primary and secondary schools established by different non-government organizations (NGOs) and the Church. Khasi found taking primary and secondary education in the neighboring country-India, through the kinship relation. Education below secondary and higher secondary level study is much higher in the Jaintiapure Punji area. The rate is $53 \%$ and $21 \%$, respectively. The frequency of higher education shows that present Khasi is entering the service sector and other education-based subsistence, rather than only depending on land for cultivation and traditional way of living. In Jaintia and Mastinghati, the higher education rate represents the exposer of the Punji in broader aspect, which has diverted the Khasi towards education and service-based subsistence pattern. Welcome Lamba, age 41, a 41 years old male Khasi living in Noksier Punji, no. 3 East Jaflong reflects his opinion on flexible practice of social rules in present time in the following description:

Case 1:

From his birth, Welcome Lamba of Noksier Punji lives in a separate house in his mother's residence yard. He lives in a separate house with his wife and children. After marriage, Welcome did not change his mother's family, only established a nuclear family in his mother's area of living. According to Welcome, as his wife is not the younger daughter of her family, she do not have inheritance right in her mother's family. Welcome has enough property, (one big Jum contains nearly 1500 - 2500 of betel leaf plants and he has the Jum area is of 2 - 3 acres, every year nearly 1000 or 1500 betel leaf trees are planted during the monsoon season) in his mother's side; he need not go to his wife's maternal inherited area. He keeps his two elder children among his seven to his wife's mother's house for better education, as his mother-in-law's house is in the Indian, and they believe that Indian education quality matches with their understanding. To visit his children, Welcome and his wife frequently travel to his mother-in-law's house. Welcome says that it is his children's decision whether they will come to their father's house or remain in their maternal grandmother's country and added that as the opportunity is better in a nearby country, he prefers to live there. [Constant conversation in the period of fieldwork].

The case study represents the segmentation of housing in the area according to rational choice supported by the traditional social network. Post-marital residence determined by the availability of subsistence space rather than the strict control of genealogy. Members of the household also remain distributed in kin-based households of different places according to the place's opportunity.

\subsection{Zamindari System and Access Barriers in Alternatives}

The availability of land and other natural resources necessary for cultivation are limiting factors and need to gain through competition and cost. The political system of landholding pattern permits the concentration of land in private ownership, and this makes others cultivate in the land through proper land rent and lease. In a Zamindar pattern, Khasi believes in a founder of the area (Ri Kinti) who distributes the land to the followers instead of rent (Khajna). By paying 
Khajna, Khasi of that Punji gets legal and mental support from Jaminder in solving legal issues of the state. The hierarchy of the Zamindar system of Khasi follows the descent line strictly. The youngest daughter of the household has authorized to be the successor with all other household responsibilities. The house where she (the Zamindar) lives is the original house of every Khasi family, and the most significant share of the household property will go to this house (ling). The following description shows the hierarchical trend of Khasi property distribution:

Case 2:

Anjali Lamba lives in Noksier Punji. In Noksier Punji, Anjali Lamba is the Zaminder. She inherited the position from her great grandmother, who was the founder of this area. The husband and sons of Anjali live with her. They work in land owned by Anjali, and they are earning considered as a common share of Anjali. Anjalis husband and son do other business and have increased property. However, according to tradition, Anjali is the head of inherited property and Jaminder of the Punji [Coted from key informant interview 2015].

The above case study has revealed that Jaminder position is associated with land ownership and decent line. In other Punji of the study area, except Sangram Punji, the single household ownership of big land area is not found, and the availability of the natural resource is also limited. The pattern of the Jamindar system does not work in the area. However, there is a ceiling of the Bangladesh Government in owning private property individually. To avoid the legal complicacy, traditional Jaminder leases the land to land-less Khasi and makes them the followers. The capital oriented precondition of becoming a leader differs from some traditional features of leadership ${ }^{10}$. The need for a Jaminder system is found applicable in Sangram and Nakshier Punji, because of ownership of big land area according to Kur (clan).

\subsection{Capital Intensive Cultivation as an Alternative}

The need for change in the production process and segmentation of land through the purchased property and private ownership reflect the limitation of the matrilineal system among Khasi, and patrilineal descent system has followed. The stimulus has changes the traditional pattern of the inherited property distribution system. The economic solvency found to be the platform for the leadership of Khasi of the area. The pattern of new leadership requires dominance over the natural resource. Through the dominance over a natural resource, which is one of the essential cultivation tools in the Khasi social system, a particular pattern of resource accumulation happens in the household of the leader. The influence of authority gets exposed through the way of investment of the resource. Following case study reflects the pattern of leadership existing in ${ }^{10}$ However, the effect of Permanent settlement in 1802, 1836 Captain Fisher's revenue assessment for Khasi Raja, selection of Jaintia Porgonas of 310,000 acres of land and bring under tax payment and Major survey of 1950 and selection of land according to the type of use, has an impact on Khasi settlement and landholding pattern. East Pakistan District Gazetteers 1971: 329-334. 
present in Khasi living:

\section{Case 3}

Paresh Lamin (pseudo name) resides in Borllah punji with his wife, and his two children study in India and come to visit parents periodically. Betel leaf Cultivation is a tiny business for him in Jaflong, and the stone business is huge demanding with lots of capital. His father lives in Srimongol, where they have a vast betel leaf garden. Paresh says, nowadays, the hierarchical property is not sufficient for one's livelihood, and the male has to earn separately. As a result, the maternal uncle's role as a guardian towards his nephews has lessened. The father has to perform his duty towards his children and wife. Thus, presently, though Khasi is matrilineal, the practical application has changed. Paresh heads in many dispute solving meetings. In these meetings, he tried to solve the problem according to the need, not only following the rules and traditions. According to tradition, after a person's death, his maternal relatives will get the property, rather than his children. However, he is against this rule, and support children should get an equal portion of his father's property along with his uncle and aunts. People now are supporting new thinking and are following it [A summary of in-depth interview on January 2015].

The case study of Paresh Lamin shows that the Khasi household is changing according to the need of subsistence. Nuclear households are growing to meet the family's need for education and service. Extension of private property and utilization of marital and kin relation to augment economic and social authority has become frequent in Khasi social system.

\section{Socio-Cultural Concerns on Adaptation}

The extrinsic factors i.e. domination, social inheritance regulations have influences on Khasi pattern of flexible economic mobility system. There is an internal effort to regulate the traditional norms with rational flexibility. The national policy regarding the regulation of small scale community needs to revise for the need to ensure the benefit accessible for the common Khasi of the community. The external forces of change needs create provision of access in mainstream cultural and economic sectors with flexible state conditions to make the change sustainable and significant to indigenous livelihood pattern. The mainstream adaptation process has lack of provision in capital centric and competitive market environment. The following discussion has explained the limited adaptation aspect from Khasi context.

\section{Adaptation Categorizes and Challenges}

The findings have elaborated here from the ground of participation (from the economic, settlement, marital, and skill aspect) in Khasis market-driven social practice. There are Jum with every household, which is cultivated mainly by household labor, both physical labor, and supervision. Every member, male and female irrespective, has a specific work to do in the Jum and its production. The 
communal effort of the household, broadly, kin group of the community, ensure the need for cultivation requirements such as preparation of the field and selling of the agro-product. In Jaflong, the concept of physical labor and supervision among the Jaminder or landowner has changed the labor utilization process. As the dependency on land and Jum cultivation through market demand increases so also the dependency on hired labor rises. Moreover, multiple Jum owners do not involve themselves in cultivation, physically. In such cases, they depend on hired laborers from inside or outside of the community.

According to the traditional rule of Khasi land ownership, the source of ownership of land has classified. Here the access to land ownership in Khasi is dominated by kinship relation ${ }^{11}$; inheritance and marital relation. The category of purchased property and lease from the government brought changes in Khasis traditional land ownership rule. Purchased property system has enabled Khasi to buy the land property and to sell it. Besides this, some people use the land and Jum independently, and they are the owners of their property. All this brings diversity and a competitive attitude in land use and ownership relation. The diversity in Khasi residence and access to land cultivation shows the Khasi traditional post-marital residence rule and access to cultivable land scattered in different places. According to ownership and cultivation, the diversified use of land in the Jaflong area has found working.

With the surplus collected from betel leaf cultivation, Khasi has to meet all household expenditures. Along with this, education and other living costs increase. The surplus coming from betel leaf and nut cultivation cannot meet the household demand. Now forest density has become thinner and larger areas of land are needed to offset the household cost. These exigencies of circumstances have led them to look for alternative sources of subsistence and income. The reflection of changes in the cultivation process can be observed on social formation patterns, as these two sectors are interactive. Here the betel leaf and betel nut cultivation depends on the support. Presently, the "involvement of effort ${ }^{12}$ " is found to be associated with "social status". The marketed division of labor imposed and various status groups of Khasi, i.e. affluent landowners, wives of rich Khasi men, headmen, and educated Khasi, do not like to involve themselves in the cultivation process physically. The process has led to the need for institutionalization of labor organization, e.g. hiring of the laborer, rather than depend on household laborer only. In the cultivation process, among the identified influential environmental components, seasonal variation has direct effects on total income. The impact of this seasonal variation led to an increase in intensive capital production and bringing stratification in the social system rather than minimiz${ }^{11}$ Work-force: pattern of kinship works as the maintaining factor of work-force among the Punji. The components, e.g. exogamous marriage rule, the role of married Pnar male towards his mother and wife's household, have influenced the management of the work-force in Punji. Besides, the increase of the community's inhabitants does have influences in the traditional management pattern of work-force among Khasi.

${ }^{12}$ Effort system: the influence of broader education and higher social status has brought changes to the traditional effort system of Khasi. 
ing the environmental limitation through technological advancement. The changes influence the cultivation purpose of Khasi. Previously, it was for a typical household or "ling". Now the involvement of rational individual decisions regarding cultivation tends to change Khasis kinship system, based on collective clan identity or "Kur".

\section{Conclusion}

The discussion of Khasis social system has reflected the pattern of change in sectional aspects and finds that the pattern of change and adaptation is not cost-effective for ordinary Khasi people. If the changes become justified by ecological and social value aspects and come from the holistic aspect of community interest, the coexistence becomes rational to its inhabitance. It will sustain as quality change, which is termed as a positive feedback of adaptation.

It found that Khasi emphasizes a supportive social system and environmental components in selecting their place of mobility and settlement. Free access to land through long time lease and abolition of Zamindary authority and purchased property are preferred by the Khasi now, as they have suffered much with various exploitative experiences with the traditional social institutions. Traditional Khasi follows household management system, i.e. the maintenance of seasonal production variation through surplus accumulated from the peak harvest period of the year. The post-marital residence, hierarchy, and leadership work for the traditional specification of Khasi living. If the pattern of change induced by different factors does not ensure the balance between internal components, then the outcome of the change will increase the social stratification and abuse of natural resources with marginalizing traditional values. The various requirements due to environmental disorders, i.e. flood, soil erosion, riverbank erosion, have compelled Khasi, presently, to invest more in the reconstruction of housing patterns, migration, and new settlement.

On the other hand, infertility and land patterns of Bollah, Mukam Punji, and Jaintiapure demonstrate the requirement of more capital on the cultivation and migration process. Along with this, changes in cultivation patterns and less dependency on environmental support for cultivation that is irrigation, artificial manuring also increase the production cost of Khasi. Theoretically, this is necessary for understanding the expected adaptation pattern in a holistic approach. The pattern of rational interaction through social and political challenges and the Khasi system's provision from the aspect of the social reproduction of small systems has analyzed in the study.

The study recommends that networking is practicing from local and individual rational and judgmental perspectives, but this should be integrated from mainstream effort considering national and broader development issues to make it a special relationship and finding functional equivalents (FEs), through the cross border or internal migration. According to Ellen (1982), every change is the nexus of dependent factors from both sides. The proper understanding of 
Khasi socio-economic preference would assist the mainstream adaptive policy formulation and sustainable development of indigenous Khasi people living in Bangladesh.

\section{Conflicts of Interest}

The author declares no conflicts of interest regarding the publication of this paper.

\section{References}

Alkire, W. H. (1960). Cultural Adaptation in the Caroline Islands. Journal of the Polynesian Society, 69, 123-150.

Ashby, W. R. (1954). Design for a Brain. Reprinted with Correction. London: Chapman and Hall. https://doi.org/10.5962/bhl.title.6969

Bareh, H. (1997). The History and Culture of the Khasi People (3rd ed.). Delhi: Spectrum Publications.

Bargatzky, T., Anderson, M., Earle, T., Ghidinelli, A., Goldschmidt, W., Peoples, G. J. et al. (1984). Culture, Environment, and the Ills of Adaptationism [and Comments and Reply]. Current Anthropology, 25, 399-415. https://www.jstor.org/stable/2742901 https://doi.org/10.1086/203159

Barth, F. (1956). Ecological Relationships of Ethnic Groups in Swat, North Pakistan. American Anthropological Association, 58, 1079-1089. https://doi.org/10.1525/aa.1956.58.6.02a00080

Bennett, J. W. (1976). The Ecological Transition: Cultural Anthropology and Human Adaptation. London: Pergamum.

Bicchieri, M. G. (1972). Hunters and Gatherers Today: A Socio-Economic Study of Eleven Such Cultures in the Twentieth Century. New York: Holt, Rinehart, and Winston.

Carneiro, R. L. (1968). Cultural Adaptation. In International Encyclopedia of the Social Sciences (Vol. 3, pp. 551-54). Chicago: The University of Chicago Press.

Chowdhury, J. N. (1998). The Khasicanvas: A Cultural and Political History. Shillong: Srimati Jaya Chowdhury.

Conklin, H. C. (1957). Hanunoo Agriculture, a Report on an Integral System of Shifting Cultivation in the Philippines (Forestry Development Paper 12). Rome: Food and Agricultural Organization of the United Nations.

Drong, S. (2012). Report from a Roundtable Held in December 7, Policy and Legal Rights of the Indigenous Life and Livelihood: Perspective of Khasi Community. Garo and Khasi Indigenous People Face Evection. BAPA and APRA. https://omiusa.org

Ellen, R. F. (1982). Environment, Subsistence, and System: The Ecology of Small Scale Social Formations. Cambridge: Cambridge University Press. https://doi.org/10.1017/CBO9780511607738

Ellen, R. F. (1984). Trade, Environment, and the Reproduction of the Local System in the Moluccas. In E. F. Moran (Ed.), The Ecosystem Concept in Anthropology (pp. 163-203). Boulder, CO: Westview Press.

Escober, A. (1996). Constructing Nature: Elements for a Post Structuralist Political Ecology. In Futures (Vol. 28, No. 4, pp. 325-43). Great Britain: Elsevier Science Ltd.

Fletcher, R. (2010). Neoliberal Environmentality: Towards a Poststructuralist Political Ecology of the Conservation Debate. Conservation and Sociology, 8, 171-181. 
https://doi.org/10.4103/0972-4923.73806

Friedman, J. (1974). Marxism, Structuralism, and Vulgar Materialism. Man, New Series, 9, 444-469. https://doi.org/10.2307/2800695

Gain, P., \& Malik, A. (2007). The Khasis of Bangladesh: A Socio-Economic Survey of the Khasi People. Society for Environment and Human Development (SHED).

Geertz, C. (1963). Agricultural Involution: The Process of Ecological Change in Indonesia. Berkeley and Los Angeles, CA: University of California Press.

Head, L. (2010). Cultural Ecology: Adaptation-Retrofitting a Concept? Progress Report in Progress in Human Geography, 34, 234-242. https://doi.org/10.1177/0309132509338978 http://www.sagepub.co.uk/journalsPurmissions.nav

Hornborg, A., Mcneill, J. R., \& Martinez-Aleir, J. (2007). Rethinking Environmental History: World-System History and Global Environmental Change. Lanham, MD: AltaMira Press.

Hulme, M. (2009). Why We Disagree about Climate Change: Understanding Controversy, Inaction and Opportunity. Cambridge: Cambridge University Press. https://doi.org/10.1017/CBO9780511841200

Kaplan, D., \& Manners, R. A. (1972). Culture Theory. Englewood Cliffs, NJ: Prentice-Hall.

Karlsson, G. B. (2015). Political Ecology: Anthropological Perspectives. In The International Encyclopedia of the Social and Behavioral Sciences (2nd ed., pp. 350-355). Amsterdam: Elsevier. https://doi.org/10.1016/B978-0-08-097086-8.12215-9 https://www.researchgate.net/publication/304194563

Klaus, V. (2010). New Year's Speech by the President of the Republic (Translated from Czech Language). http://www.klaus.cz/clanky/2491

Kroeber, A. L. (1939). Culture and Natural Areas of Native North America. Berkeley, CA: University of California Press.

Lapka, M., Vavra, J., \& Sokolickova, Z. (2012). Cultural Ecology: Contemporary Understanding of the Relationship between Humans and the Environment. Journal of Landscape Ecology, 5, 12-24. https://www.researchgate.net/publication/255723360

Lorenzoni, I., Nicholson-Cole, S., \& Whitmarsh, L. (2007). Barriers Perceived to Engaging in Climate Change among the UK Public and Their Policy Implications. Global Environmental Change, 17, 445-459. https://doi.org/10.1016/j.gloenvcha.2007.01.004

Matley, I. M. (1982). Nature and Society: The Continuing Soviet Debate. In Progress in Human Geography (Vol. 6, pp. 367-96).

Meggitt, M. (1972). System and Subsystem: The TE Exchange Cycle among the Mae Enga. Human Ecology, 1, 111-123. https://doi.org/10.1007/BF01531350

Milton, K. (1993). Environmentalism: The View from Anthropology. London and New York: Routledge.

Molland, S. (2018). Sedentary Optics: Static Anti-Trafficking and Mobile Victims. In The Wenner-Gren Foundation for Anthropological Research (Ed.), Current Anthropology (Vol. 59, No. 2, pp. 115-137). . Chicago: Chicago University Press.

http://www.journals.uchicago.edu/t-and-c

https://doi.org/10.1086/697199

Moran, E. F. (2000). Ecological Anthropology: History, Theory, and Method (Part One). In E. F. Moran (Ed.), Human Adaptability: An Introduction to Ecological Anthropol$o g y$ (p. 2). Boulder, CO: West View Press.

Murdock, G. P. (1949). Social Structure. New York: Macmillan Co.

Patam, R (2005). The Khasi Peoples: History, Heritage and Culture (Written in Bengali 
Language) (pp. 93-189.). Dhaka: Barsha Private Ltd.

Rappaport, R. A. (1967). Ritual Regulation of Environmental Relations among a New Guinea People. In A. P. Vayda (Ed.), Environment and Cultural Behavior: Ecological Studies in Cultural Anthropology (pp. 181-201). New York: Doubleday \&Company, Inc.

Sahlins, M. D. (1957). Land Use and Extended Family in Moala, Fiji. In A. P. Vayda (Ed.), Environment and Cultural Behaviour: Ecological Studies in Cultural Anthropology (pp. 395-415). New York: Doubleday and Company, Inc.

Simoons, F. J. (1979). Questions in the Sacred-Cow Controversy [and Comments and Reply]. In Current Anthropology (Vol. 20, No. 3, pp. 467-93). Chicago: The University of Chicago Press. https://www.jstor.org/stable/2742106

https://doi.org/10.1086/202319

Steward, J. H. (1955). Theory of Culture Change. Urbana, IL: University of Illinois Press.

Vayda, A. P. (1969). Environment and Cultural Behavior: Ecological Studies in Cultural Anthropology. New York: Doubleday \& Company, Inc.

Wolf, E. (1972). Ownership and Political Ecology. Anthropological Quarterly, 45, 201-205. https://doi.org/10.2307/3316532 